\title{
Implementation of Regulation Number 25 in 2009 Concerning the Public Services Toward the Regional Organizations of Gorontalo District
}

\author{
Muten Nuna \\ Faculty of Law, Gorontalo University, Gorontalo, Indonesia, Jl. Ahmad A.Wahab \\ No. 247, Kayubulan, Limboto, Gorontalo \\ E-mail: mutensnuna@gmail.com \\ Ibrahim Ahmad \\ Faculty of Law, Gorontalo University, Gorontalo, Indonesia, Jl. Ahmad A.Wahab \\ No. 247, Kavubulan, Limboto, Gorontalo \\ E-mail: ibrahimahmad.ug@gmail.com
}

\section{Arifin Tumuhulawa}

Faculty of Law, Gorontalo University, Gorontalo, Indonesia, Jl. Ahmad A.Wahab No. 247, Kayubulan, Limboto, Gorontalo

E-mail: tumuhulawa.arifin@gmail.com

\section{Dikson Junus}

Faculty of Social and Political Sciences, Gorontalo University, Gorontalo, Indonesia, Jl. Ahmad A.Wahab No. 247, Kayubulan, Limboto, Gorontalo

E-mail: diksonjunus@gmail.com

Roy Marthen Moonti

Faculty of Law, Gorontalo University, Gorontalo, Indonesia, Jl. Ahmad A.Wahab No. 247, Kayubulan, Limboto, Gorontalo

E-mail: roymoonti16@gmail.com

\begin{abstract}
The research aimed to investigate the effectiveness of Regulation Number 25 in 2009 concerning public service on the organization of the local forces and investigate the hindrance factors of the implementation of Regulation Number 25 in 2009 concerning public service on the regional organizations. It was empirical juridical research employing the interview method. The technique of data analysis applied descriptive analysis. Findings revealed that the public services of Gorontalo District's regional organizations had been implemented based on the procedure operational standard and the provision of Legislation, although it was not effective. It can be seen from community satisfaction with administrative services that still need to be addressed and improved. The hindrance factors of implementing public service regulation were human resources and the availability of facilities and infrastructures. In creating public services appropriately with the Legislation, the government should be entirely done to improve employees' awareness. Society or paying attention to the organization management and adequate human resources and facilities and infrastructures can support the role of government in improving the public services, particularly the regional organizations of Gorontalo District.
\end{abstract}

Keywords: public services; organization; local government.

Implementation of Regulation Number 25 in 2009 Concerning the Public Services toward the Regional Organizations of Gorontalo District Muten Nuna, Ibrahim Ahmad, Arifin Tumuhulawa, Dikson Junus, Roy Marthen Moonti 


\section{INTRODUCTION}

Indonesia is a unitary state in a Republic explained in 1945 constitution, Article 1, The Constitution of The Republic of Indonesia. As the unitary state concept, all regions in Indonesia were in unity or known as the national government. It is explained in the 1945 constitution, Article 18, verse 1, which stated that "The Republic of Indonesia is divided into provinces. Each province consisted of districts and cities in which each district and city consisted of local government-regulated in the regulation.

The 1945 constitution, Article 18, verse (1) states that in implementing the administrations, each region has authorities. Article 18, verses (2) and (5) states that each province, district, and city in Indonesia regulates and manages government affairs according to autonomy and assistance task principles. The local governments are given extensive autonomy.

Authorities of local governments are mandated in the 1945 Constitution and then are explained in Regulation Number 2 in 2014 concerning the Local Administrations. The implementation of local governments is to accelerate the establishment of community's prosperity through the improvement of services, empowerment, and contribution of people, and the increase of competitiveness of regional by paying attention to the principles of democratic, even distribution, justice, and characteristic of a region in the system of the Republic of Indonesia.

The arrangement and management of local government are regulated appropriately to the provision of Article 18, verse 7 of the 1945 Constitution. The existence of regulation concerning the local administration makes each local government has its authority in regulating and arranging its territory. The local autonomy aims to create a division of power between established regions in which the central government can increase its capacity, obtain people's support, and control the division of human resources evenly. One of the local autonomy philosophies is to maximize public services. Therefore, the public services are essential things of the local autonomy.

Services provided to the community and law enforcement for the administration of the state and government are an inseparable part of efforts to realize good, clean, and efficient governance to improve welfare. It is realizing justice and legal certainty for all people as stated in the 1945 Constitution. The aspirations that develop in the community are to be more effective and efficient, honest, clean, transparent, free from corruption, collusion, and nepotism of state and government administrators.

Satjipto Rahardjo in Suparman (2014) explains that to enforce public service law, public service providers must avoid the usual or conventional ways but must do so in an extraordinary way (progressive law enforcement), meaning to work vigorously. determination, right, and not the same as "justifying all kinds of ways."

Implementation of Regulation Number 25 in 2009 Concerning the Public Services toward the Regional Organizations of 


\section{Jurnal Ilmiah Al-Syir'ah Vol. 19, No. 2 (2021): 165-181 \\ Website: http://journal.iain-manado.ac.id/index.php/JIS \\ ISSN 2528-0368 (online) ISSN 1693-4202 (print)}

The public services are related to comprehensive life aspects. In-state life, the government has a function to provide various public services required by society either in regulation or other services to fulfill the people's needs in education, health, utility, etc. Some public reform movements experienced by developed countries in the early 1990s are very much inspired by people's pressure to improve public services quality provided by the government.

The central government in the decentralization system had handed over specific government affairs to local government; hence the responsibility to provide the public services is in the local government's hands. Considering the local autonomy principles in the unitary state, the autonomy in the implementation of that affair should be limited by the existing state as the highest institution formed by the consensus of people in the particular territory, with construction and specific arrangements that have been compiled and agreed together to regulate the life.

By the existence of the functional, officially, Regulation Number 25, 2009 concerning the public services has been issued, a regulation to regulate the sound government principles as the effectiveness of government functions itself. To create the public services implementation, bureaucrats should focus on the customer's satisfaction-oriented management. A writer named Obsome stated it with the customer-driven government. It means that the government is demanded to focus on the management and community empowerment functions and implement the competition system in public services providing, prioritize the services decentralization, and implement it in the market system in providing services. In running its function to give the services to people, the government had been issued a policy in the form of Regulation Number 25, 2009 about public services. This policy is to maximize the services. Thus, it can create the climate of the prima service in each government institution.

Regulation Number 25 in 2009 concerning public services has not yet been done maximally by the government. For example, what happened in the Gorontalo District government is that the services provided by the society have not been effective and efficient. Thus the services obtained by the people in the institutions are not appropriate to the expectation. Therefore, the Gorontalo District government constantly improves the public services in all Regional Forces Organization after obtaining a lack of compliance value from the survey of Ombudsmen of Republic of Indonesia Representative in Gorontalo Province.

Initially, the Ombudsmen of the Republic of Indonesia Representative in Gorontalo Province stated that the Gorontalo District government became the implementer of public services lacking compliance value or in the red zone. It is found in a survey of compliance of Regulation Number 25, 2009 concerning Public Services in 2016. The data obtained showed that the compliance value of the Gorontalo District government was 30,76, which the value places the Gorontalo District Government in the $74^{\text {th }}$ out of 85 Surveyed District Government and is in the red zone. The survey result in 2017 shows that

Implementation of Regulation Number 25 in 2009 Concerning the Public Services toward the Regional Organizations of 
Gorontalo District is still lacking compliance. The Gorontalo district government can only collect a score of 22,94 and is in $97^{\text {th }}$ place out of 104 surveyed local governments. In 2018, Gorontalo District was in a yellow zone by collecting a score of 73,17 and placed in 82th out of 199 assessed districts.

The discipline factor of the state civil apparatus in improving the quality of service to the community is still lacking. The overlapping of regulations and policies of the central government has created confusion among policy implementers in the regions. It has resulted in lengthy bureaucracy and slow processes. The lack of public services level in Gorontalo District became a problem in providing services to society. To improve the quality of public services implementation, which is superfine and fulfills each citizen's basic needs and civil rights on the public service, it needs public service standard determined through Local Regulation based on Law Number 25 of 2009 concerning Public Services. People always demand qualified public services from the bureaucrat, although that is not appropriate to the expectations. Empirically, the public services during this time are still convoluted, slow, and tiring. The community does not get its satisfaction with the services provided because it is too bureaucratic, slow, and makes people bored with the length of time the services are provided. This tendency is because society is still positioned as the service provider, not the people who get the services. The people who should be provided with services sometimes turn into the ones who provide the service. Even though, The state is established for people as the establishers. Thus, it needs collaboration and synergy between government and society, particularly in Gorontalo District, to facilitate public services.

\section{RESEARCH METHODS}

It applied empirical juridical research. It is a sociological, legal research type and can be called field research. It studies the applicable legal certainty and what happened in the society (Waluyo, 2002). In other words, it is research conducted toward the actual situation that occurred among people to investigate and find out the facts and data. After the data are collected, the problem identified, which leads to problem-solving, is done.

\section{RESULTS AND DISCUSSION}

The Effectiveness of the Implementation of Regulations Number 25, 2009 Concerning the Public Services in Gorontalo District Organizations

In essence, the government provides services to the community. The government is held not to serve itself but to provide services to the community and create conditions or situations that allow every community member to develop their abilities and creativity to achieve common goals (Wibawa, 2019).

The government is the only party obliged to provide pure public goods about the nature of private goods and pure public goods, especially public goods

Implementation of Regulation Number 25 in 2009 Concerning the Public Services toward the Regional Organizations of 


\section{Jurnal Ilmiah Al-Syir'ah Vol. 19, No. 2 (2021): 165-181 \\ Website: http://journal.iain-manado.ac.id/index.php/JIS ISSN 2528-0368 (online) ISSN 1693-4202 (print)}

called rules (public policy). The regulation's provision of pure public goods is never and should not be handed over to the private sector. Generate private interests that make the rules so that the rules become full of vested interests and become unfair (unfair rule). The role of the government that will remain attached throughout its existence is as a provider of pure public goods called rules (Cahyadi, 2016).

In Indonesia, the effort to determine the public service standard to increase the public services quality was made a long time ago. The efforts are shown in some policies such as Regulation Number 25, 2009 about the public policies. However, the public services standard is still in concept while the implementation is still far from the expectation. It is proven by some government institutions' lack of service quality as the public services implementer.

Public services are all kinds of public services implemented by government institutions, whether the central government, local government, Stateowned entrepreneurship, or regional-owned entrepreneurship in the form of goods and services. Besides, the public services have been conducted in some fields through government administration or well-known as public administration. The services are well-implemented either to fulfill the people's needs or as the implementation of regulations determination.

Based on Article 5 verse, Regulation Number 25, 2009, the scope of public services includes providing goods and services to the public and administrative services in regulations. The goods service provisions indicated in verse (1) include: First, the procurement and distribution of public goods that is conducted by government institution which its half or whole fund is from state revenue and expenditure budget and regional revenue and expenditure budget; Second, an enterprise conducts the procurement and distribution of public goods. The half or whole budget for its construction capital is from national wealth and separated regional wealth; Third, procurement and distribution of public goods whose sources of funds are not from the state revenue and expenditure budget and from regional revenue and expenditure budgets or from business entities whose half or all of the budget for development capital comes from state assets and from separated regional assets, but procurement is a state mission regulated in legislation.

In Gorontalo District, the procurement of goods and services has been regulated in Regent's Regulation of Gorontalo Number 5, 2016 about the guidelines of the procurement of goods and services in villages, where the financing is from The Village Revenue and Expenditure Budget. As explained in Article 4 verse (1), the scope of the arrangement of the procedures for implementing goods and services procurement in the Gorontalo Regent's Regulation is the goods and services which the fund is from the Village Revenue and Expenditure Budget.

Implementation of Regulation Number 25 in 2009 Concerning the Public Services toward the Regional Organizations of 


\section{Jurnal Ilmiah Al-Syir'ah Vol. 19, No. 2 (2021): 165-181 \\ Website: http://journal.iain-manado.ac.id/index.php/JIS ISSN 2528-0368 (online) ISSN 1693-4202 (print)}

The responsibilities of public goods services have been given entirely to the Department of Industry and Commerce of Gorontalo District, including technical guidance, export and import, domestic and foreign trade, distribution of goods and services, and the activities of measuring, weighing, and the equipment used by the entrepreneur as have been regulated in Article 7 Gorontalo Regent's Regulation Number 40, 2016 about the position, organizational structure, tasks and functions, and work procedure of Department of Industry and Commerce.

The contents of Article 17, Gorontalo Regent's Regulation Number 8 in 2018 are the division of enterprise guidance and commerce promotion has the task of preparing and implementing the technical guidance of business development, facilities, export and import activities, domestic and foreign trade, distributing the goods and services, controlling the license and monitoring the company registration, and preparing and reporting the data, and the Standardization and Commerce Division has the task of checking the standards listed on goods circulating in the community, supervising trade licensing, controlling the procurement and circulation of supervision goods, and processing orderly trade data controlling managing. Standard equipment, monitoring, evaluation, and orderly commercial reports and the implementation of other official duties.

Yolansawati Amir as the Head of the Regional Technical Service Unit of the Legal Metrology Service of the Industry and Trade Office of Gorontalo Regency, which directly handles public goods services, stated that public services at the Industry and Trade Office had been running well according to Standard Operating Procedures. and by applicable regulations where all services are provided such as identification of the type of goods related to size, measurement, balance, and equipment. Then it is measured, weighed, weighed, and the equipment is tested and validated or sealed, which will then be reconsidered for mass and weight, and all is done quickly and does not take much time.

Based on the findings through a direct interview conducted in the field, the service of the public good at the Department of Industry and commerce of Gorontalo District has been appropriately conducted based on the procedure operational standard and the applicable regulations. Hence, public services can be provided quickly and appropriately. Besides, it is a task and authority mandated by the applicable regulations.

In implementing public services, the Gorontalo District Government has tried to improve the quality of the service to the community, when each year improved and showed and progress significantly from 2016 to 2018. It indicates that the local government is very enthusiastic and has a high spirit of improving the service quality in Gorontalo District appropriate to the services standard and the applicable regulations.

The same thing was conveyed by Yolanda Puluhulawa (Head of the Health Office of the Gorontalo District Health Office), who directly handles health services whose implementation of services to the community as providing

Implementation of Regulation Number 25 in 2009 Concerning the Public Services toward the Regional Organizations of 


\section{Jurnal Ilmiah Al-Syir'ah Vol. 19, No. 2 (2021): 165-181 \\ Website: http://journal.iain-manado.ac.id/index.php/JIS ISSN 2528-0368 (online) ISSN 1693-4202 (print)}

administrative services including health insurance, is by Standard Operating Procedures. and applicable conditions.

Based on the finding in the field through direct interviews, regional organizations, which is the Department of Health, had shown good work when every procedure of services had been appropriate to the Procedure Operational Standard and the applicable regulation. Thus, the people who need the services are pretty facilitated with all efforts and challenging works of the government in improving the regional service quality.

The service standard is a basis used as the guideline for implementing services. The references of the services quality assessment become the responsibilities and promises from the implementer to the people for quality, quick, easy, economical, and measurable services. The public services are activities to fulfill the required services based on each citizen's applicable regulations on the public services implementers' goods, services, and administrative services. The responsibility of the government is to provide public services that become the right of each citizen.

The responsibilities of the government and the rights of people have been stated in the constitution of a nation. One of the responsibilities of the government regulated in the regulations about public services is administrative service which is comprised of two: First, the government administrative action is the service to provide documents from the government from the certificate of birth to the certificate of death, including everything needed by citizens in running their lives, such as obtaining the license to build a building, enterprise license, land certificate, and marriage certificate. Second, the non-government administrative action is the service to provide documents out of the government institutions such as banking affairs, insurance, health, security, industry area management, and social activities management.

This statement is very different from the statement of Karmeng Imran (Head of the Population Registration Service, Gorontalo Regency Population and Civil Registration Office) that population administration services or legal documents needed by the community such as ID cards, family cards, birth certificates, death certificates, etc. Although it is by Standard Operating Procedures, the services provided are still not optimal. Therefore, until now, it is still being improved.

The findings through interviews revealed that the administrative services at the Department of Population and Registration of Gorontalo District are considered good. It has been running based on the services standard and the applicable regulations. However, the administrative services still need improvement. It is due to the level of people's satisfaction is still low to the service provided. Hence, the Gorontalo District Government should improve either the human resources or the facilities and infrastructures.

Implementation of Regulation Number 25 in 2009 Concerning the Public Services toward the Regional Organizations of 


\section{Jurnal Ilmiah Al-Syir'ah Vol. 19, No. 2 (2021): 165-181 \\ Website: http://journal.iain-manado.ac.id/index.php/JIS ISSN 2528-0368 (online) ISSN 1693-4202 (print)}

The public services should be done professionally to create the condition that enables people to develop their capability and creativity to manage and determine their future. The professional public services are the public services with accountability and responsibility from their implementer (government apparatus) by having the following characteristics: effective, simple, transparent, efficiency, transparency is the procedure for requirements, the punctuality, responsive refers to quick response to what becoming problems and the need in aspiration of people who get the services and adaptive is quick to adjust to the demand, willingness, and aspiration of people who get the services; it should continuously improve.

The Gorontalo Regency Government should continue to optimize quality public services to the community so that public services carried out can run more optimally. It aims to create a public service organization that is smaller (small, efficient), faster (fast, effective performance), cheaper (cheap operation), and competitive. Thus, public services in Gorontalo Regency can become more optimal and accountable.

\section{The Hindrance Factors of the Implementation of Regulation Number 25 in 2009 about Public Services in the Regional Organization of Gorontalo District}

The main problem that becomes the hindrance of public service is improving the quality of public services itself. The qualified public services are influenced by the supporting human resources, facilities and infrastructures.

Government organizations or a company should have vital human resources. The resources required by a company or an organization cannot be considered self-supporting but a strong unity that forms a synergy. The role of human resources is very determining. Human resources are also called a workforce by some experts. Some people catch the human resource definition with personal (personal, employee, etc.). Human resource has intellect, feeling, willingness, skill, knowledge, encouragement, power, and work (ratio, feeling, and intention).

Sutrisno (2013). states that al potential of human resources influenced the organization's effort in achieving the targets. Although with the development of technology and information, the availability of capital, and adequate material, it will be difficult for the organization to achieve its goals without human resources. Werther and Davis state that human resources are ready, capable, and prepared to achieve the organization's goals. As already stated that the primary dimension of human resources is their contribution to the organization. In contrast, the primary dimension of humans is the contribution dealt toward themselves, which will determine their lives quality and capability

High-quality human resources, according to Ndraha (1999), is capable of creating not only the comparative value but also the competitive-generative-

Implementation of Regulation Number 25 in 2009 Concerning the Public Services toward the Regional Organizations of 


\section{Jurnal Ilmiah Al-Syir'ah Vol. 19, No. 2 (2021): 165-181 \\ Website: http://journal.iain-manado.ac.id/index.php/JIS ISSN 2528-0368 (online) ISSN 1693-4202 (print)}

innovative value using the highest energy such as intelligence, creativity, and imagination; not only using gross energy such as raw material, land, water, muscle power, etc.

Based on some definitions, it should be understood that human resources should be indicated as power sources from humans that the organization can utilize. Human resources are humans that have resources and power. This opinion is relevant to the thinking framework that the quality and competence of resources should be improved to be a power.

In Gorontalo District, human resource is still one of the internal factors that play a significant role in achieving its goals. Thus better management of human resources is needed. The organization should unite the perception between its employees and leader to achieve the service goals. Government organizations should also create reliable and skilled human resources to support the service provided to the community. Besides having reliable and competent human resources, the government should provide their employees with adequate facilities and infrastructures to support the employees in implementing the public services based on the Procedure Operational Standard and the applicable regulations.

Sri Rhamawaty Bakar (The Head of Energy and Mineral Resources Division at Department of Industry and Commerce of Gorontalo District), says that the lack of experts sometimes makes the services provided to the public is not efficient. Thus, the lack of human resources can obstruct the excellent services to the community.

Thomas Panigoro (The Secretary of Department of Population and Registration of Gorontalo District) that the lack of competent human resources, equipment, and machine, including the internet connection and work environment, are the hindrance factors the public services.

About the service problem handling, the probability of front-line staff is minimal. In contrast, the probability of community meeting the person in charge for services to overcome the problem is complicated. As a result, some problems of services need a very long time to be handled. In terms of human resources, the main weaknesses of human resources are related to professionalism, competence, empathy, and ethics.

The management of facilities, infrastructures, and/or the public service facilities has been explained in Article 25, Regulation Number 25 in 2009 about the public services namely: (1) the organizers and the implementers are responsible to manage the facilities, infrastructures, and/or services facilities effectively, efficiently, transparently, accountably, and continuously and responsible to the maintenance and/or the replacement of facilities, infrastructures, and/or the public service facilities; (2) the implementers are responsible to report to the organizers about the condition and requirement of facilities, infrastructures, and/or the public service facilities and the implementation should be appropriate

Implementation of Regulation Number 25 in 2009 Concerning the Public Services toward the Regional Organizations of 


\section{Jurnal Ilmiah Al-Syir'ah Vol. 19, No. 2 (2021): 165-181 \\ Website: http://journal.iain-manado.ac.id/index.php/JIS ISSN 2528-0368 (online) ISSN 1693-4202 (print)}

to the service standard requirement demand; (3) based on the report of condition and requirement as has been stated in verse (2), the organizers analyze and arrange the list of requirement for facilities, infrastructures, and/or the public service facilities; (4) based on the analysis and list of requirements as stated in verse (3), the organizers should procure based on the applicable regulations by considering the principles of effectiveness, transparency, accountability, and continuity.

In line with the previous statement, Adhan Mohi (Staff of the Gorontalo City Health Office) said that the lack of awareness of duties and responsibilities, lack of communication with the community, and inadequate facilities and infrastructure were obstacles and factors related to the provision of health services.

Based on the findings through an interview conducted with some institutions in Gorontalo District about the hindrance factors of the public services regulations, the researcher has analyzed that the lack of human resources and the inadequate capability become the hindrance factors to providing public services. The unavailability of facilities and infrastructures can also obstruct the process of service provision. Hence, the implementation of public services regulations cannot be run well appropriate to the expectation and the applicable statutory provisions.

\section{Roles and Efforts to Support Regulation Number 25 in 2009 Concerning the Public Services in Gorontalo District Organizations}

The public services provided to people will be run well as expected based on the Legislation if roles and efforts to support it are adequate and can function effectively and efficiently. According to Moenir, there are some efforts to support the implementation of proper services: (1) the awareness of the officials and employees in public services; (2) the regulation that becomes the basis of service work; (3) organization that becomes instrument and system enabling the service activity mechanism to run; (4) the employees' income to support the implementation of activities, (5) the employees' skills and capabilities, and (6) facilities in the implementation of services. The six factors have different roles but influence each other and simultaneously create the optimal service implementation: verbal services, written services, or movement or action (Moenir, 2008).

First, the awareness of the officials and employees who work in public services. Awareness is a thinking process through reflection, consideration, and comparison methods; hence it produces the belief, calmness, determination, and balance in the soul as the basis of behavior and action that will be made. Awareness has a function as a basis for taking action. This awareness can bring a person to sincerity in carrying out or carrying out his will. Willingness in the organizational environment is manifested in written and unwritten tasks and binds everyone in an organization.

Implementation of Regulation Number 25 in 2009 Concerning the Public Services toward the Regional Organizations of 


\section{Jurnal Ilmiah Al-Syir'ah Vol. 19, No. 2 (2021): 165-181 \\ Website: http://journal.iain-manado.ac.id/index.php/JIS ISSN 2528-0368 (online) ISSN 1693-4202 (print)}

Work awareness is the awareness to carry out the tasks that are one's responsibility about the completeness and correct reporting of work to improve work results. Awareness has a positive impact on organizations and jobs. This awareness is a source of sincerity and discipline in carrying out their duties. Thus, the results are expected to meet the applicable standards, both implementation standards, and operational standards. Karmeng Imran delivers it (The head of Population Registration Services Division, Department of Population and Registration of Gorontalo District) that the awareness of the officials or employees in providing the services has been good in which they are responsible for providing the services to people based the Procedure Operational Standard and applicable Legislation.

Yolansawati Amir also conveyed the same thing, as the Head of the Legal Metrology Regional Technical Service Unit of the Industry and Trade Office of Gorontalo Regency that related officials or employees must provide services to the community because service is an obligation that must be carried out. Based on the findings in the field through interviews, all employees in the Gorontalo Regency regional apparatus organization showed a positive attitude. They have carried out their duties and functions with full awareness as stipulated in the Legislation. However, this attitude must be maintained or even improved.

The improvement of public services in Indonesia is very dependent on the role of the leader of the government's institutions (either the officials or the employees). The organizations have credible and high integrity leaders and vision to be role models and innovators for public services reformation. The awareness of the officials and employees who work in public services shows a condition of someone's soul, which is an equilibrium of some consideration. Thus, it gains a belief, calmness, determination, and balance in one's soul. Moenir (2008) formulates that awareness is a process of thinking through reflection, consideration, and comparison. Hence, it produces the belief, calmness, determination, and balance in the soul as the basis of behavior and action that will be made.

The awareness can bring someone to the sincerity in running or implementing their willingness. The organization's willingness is explained in the form of a task, whether written or unwritten, and it ties all people in an organization. Thus, the service process full of sincerity and discipline will be reflected through their attitude and behavior.

Second, the regulation that becomes the basis of service work. Regulation is a set of critical equipment in every action of people. The more developing and plural the community, the bigger the regulation's role and it can be stated that people cannot live comfortably and adequately without regulation. Regulation in an organization has a function to tie all members in order the organization to run based on the regulation itself, and the organization will have direction and goal. In the organization, the regulation includes both written or unwritten provisions such

Implementation of Regulation Number 25 in 2009 Concerning the Public Services toward the Regional Organizations of 


\section{Jurnal Ilmiah Al-Syir'ah Vol. 19, No. 2 (2021): 165-181 \\ Website: http://journal.iain-manado.ac.id/index.php/JIS ISSN 2528-0368 (online) ISSN 1693-4202 (print)}

as work time, disciplines in working, sanction to the work violation, and other applicable provisions.

The assessment of government apparatus performance has been done externally, which is by the response of people's satisfaction. The government arranges the instrument to measure the performance of the public service externally through the Decree of Menpan Number 25/KEP/M.PAN/2/2004. Based on the ministry of state apparatus utilization number 25/KEP/M.PAN/2/2004 about the general guideline of the arrangement of community's satisfaction index at government institution unit, there were 14 indicators of performance to measure the organization's performance as follows: First, the service procedures, the facilitation of the services stages given to people observed from the simplicity of the service flow; Second, the service requirement, the technical and administrative requirements needed to get the service based on the types of service; Third, the clearness of service workers, the existence and certainty of workers who provide services (name, position, and authorities and responsibilities; Fourth, disciplines of service workers, the sincerity of the workers in providing services, particularly the work time consistency which is based on the applicable provision; Fifth, responsibility of service workers, the clearness of authorities and responsibilities in implementing and completing the services.

Sixth indicator is the capability of service workers, the level of capability and skill owned by the workers in providing/completing the services to people; Seventh, the speed or service, the target of service time that can be done in a certain period by the service implementer unit; Eighth, fairness in getting service, the implementation of service by not differentiating people by their class and status; Ninth, courtesy and friendliness of workers is the attitude and behavior of workers in providing services to people in a polite and friendly manner and with mutual respect; Tenth, the fairness of service price, an affordable price determined by service unit.

Eleventh indicator is the certainty of the service price, the adjustment between paid the price and determined price; Twelfth, the certainty of service schedule, the implementation of service time based on the applicable provision; Thirteenth, the convenience of environment, the condition of facilities and infrastructures which are clean, neat, and orderly, hence, can bring comfort to customers; Fourteenth, the security of service, the guarantee of the level of security at service implementer unit environment or the used facilities, thus, the people will be secure to get services from risks of the implementation of services.

The indicators of the organization's performance measurement criteria should become the basis or reference in running tasks. Therefore, according to the results of an interview with Adhan Mohi (Puskesmas staff at the Gorontalo City Health Office), the regulations that are the reference in providing services are significant because they can be legal protection for workers when unintentional errors occur during the provision of services.

Implementation of Regulation Number 25 in 2009 Concerning the Public Services toward the Regional Organizations of 


\section{Jurnal Ilmiah Al-Syir'ah Vol. 19, No. 2 (2021): 165-181 \\ Website: http://journal.iain-manado.ac.id/index.php/JIS ISSN 2528-0368 (online) ISSN 1693-4202 (print)}

It is slightly different from what has been stated by Karmeng Imran (The head of Population Registration Services Division, Department of Population and Registration of Gorontalo District) that regulation which becomes the reference has been clear enough. Yet, there should be an improvement based on the condition and place.

Based on the findings through the interview, the service employees or workers at Gorontalo District Organizations have made the regulation as the guideline or reference to implement the service task and made the regulation the legal guarantee or legal certainty if something happens out of the service corridor. However, the regulation should be made based on the need and condition of the place.

Third, organization as the instrument that enables the service activities mechanism to run. The service organizations are not different from other organizations in general. However, there are some differences in their implementation. It is because the targets of service are particularly for humans that have multi-complex characteristics and willingness. Therefore, the organizations meant here are not in the formation of organizational structures. Still, it is more to the regulation and mechanism or work that can create adequate services.

The organization arranges structures that describe the hierarchy of accountability and work division based on the expertise and function of each member in each division appropriate to the determined task and efforts of organization development. Besides, the organization also regulates the systems, procedures, and methods that function as the work procedures so that the implementation of work can run smoothly and successfully. Organization as a system is an effective instrument in achieving goals. In this case, good and satisfaction services should be well-attached in the body of the implementers, particularly the Organizations in Gorontalo District.

Thomas Panigoro (Secretary of the Gorontalo Regency Population and Registration Office) stated that government organizations such as the Population and Registration Office are organizations whose main tasks and functions are to provide services to the community based on Standard Operating Procedures and statutory regulations and has established organizational procedures in carrying out the function of providing services properly.

Based on the findings in the field through the interview, in principle, as the organizations that have a responsibility to provide services to people, they should always run the regulated mechanism through Legislation and Procedure Operational Standard to facilitate the service task implementation to people. The regional organizations in Gorontalo District have organized the organization procedures and the task and function that become the reference of tasks implementation to achieve the goals.

Implementation of Regulation Number 25 in 2009 Concerning the Public Services toward the Regional Organizations of 


\section{Jurnal Ilmiah Al-Syir'ah Vol. 19, No. 2 (2021): 165-181 \\ Website: http://journal.iain-manado.ac.id/index.php/JIS ISSN 2528-0368 (online) ISSN 1693-4202 (print)}

Fourth, the employees' income that has a function as the service implementation support. Income is all revenues of somebody as the reward on power and thought given to other people, either in money or facilities during a specific period. The income influences the employees' performance. If it is not enough to fulfill the minimum basic need, it will cause anxiety and influence society's services quality. Hence, the employees will do another job out of his tasks to fulfill their life requirements.

Mangkunegara states that compensation given to employees entirely influences the level of work satisfaction and work motivation and achievement. The research about the individuals' attitudes in the organization shows that reward is the most critical factor. Because it is crucial for many people, the reward strongly influences their attitudes and achievements. The improvement of achievement is influenced by motivation theories referring to needs satisfaction and other related factors. It assumes that effective organizations can motivate the members through various ways such as the need for money, status, success, and work condition.

Yolansawati Amir has said as the head of Local Technical Services Unit for Legal Metrology of Department of Industry and Commerce of Gorontalo District that, in principle, the level of income of employees is a factor of motivation support to improve the performance of providing service to people.

Based on the findings in the field through the interview, the incentive given to the employees in providing services at Organization in Gorontalo District is always done because it is one of the factors to motivate the employees or workers to improve their performance in providing service. Thus, motivation also influenced the improvement of good services to people. Therefore, reward giving can always change employees' attitudes in providing services to give their best performance.

Fifth, employees' capabilities and skills. Employees' capabilities can influence service quality because generally, employees who have capabilities and skill will run their tasks in services providing field and straightly face the customers. With adequate capabilities and skills, the implementation of tasks can be done quickly and adequately and can fulfill the need of all parties. Employees' capabilities can be increased by giving guidance and work instructions, and training and education special for the employees because they were fundamental in improving their capability.

Hani (2000) utters that education and training (development) have a broad scope to improve and increase knowledge, skill, attitude, and characteristics. However, Hasibuan defines education and training as an effort to improve the employees' technical, theoretical, conceptual, and moral skills according to their work/position (Hasibuan \& Hasibuan, 2016).

Implementation of Regulation Number 25 in 2009 Concerning the Public Services toward the Regional Organizations of 


\section{Jurnal Ilmiah Al-Syir'ah Vol. 19, No. 2 (2021): 165-181 \\ Website: http://journal.iain-manado.ac.id/index.php/JIS ISSN 2528-0368 (online) ISSN 1693-4202 (print)}

Based on the two definitions, it can be concluded that education and training is important problem in both government institution and company. To achieve their goals, they need qualified and skilled laborers obtained from education and training - the education and training in government institutions or companies to improve their employees' skills and knowledge.

Thomis Panigoro (The Secretary of Department of Population and Registration of Gorontalo District) declares that the employees, particularly the operators, should have capabilities and skills related to the mastery of technology and information and minimally can operate the computer. Thus it can support the speed of working in providing the services.

The same thing was also expressed by Yolanda Puluhulawa (Head of the Health Office of the Gorontalo District Health Office) that in principle skills are by each person's profession, but in improving the abilities and skills of each employee, participation in health training must accompany it.

Based on the findings in the field through the interview, the Gorontalo District Government often asks their employees to participate in education and training related to the development of capabilities and skills. Therefore, capabilities and skills are the support in improving the quality of the service. Besides the formal activities, it also needs the improvement of capabilities and skills through non-formal activities. The skilled employees are mainly possible to perform satisfactory work.

Sixth, facilities in implementing the service tasks. The service facilities meant here are all work equipment and facilities that function as social supporting instruments on behalf of people related to the organization. The facilities and infrastructures can influence the service quality because they are the main or supporting instruments in task implementation. Besides, service facilities can accelerate the task implementation process, improve productivity, create comfort for related people, and bring satisfaction. Therefore, each service implementation, particularly Gorontalo District Government, should be concerned about the availability of adequate facilities and infrastructures.

Karmeng Imran (The head of Population Registration Services Division, Department of Population and Registration of Gorontalo District) appeals that the facilities and infrastructures have been adequate because the instruments and sophisticated application support them. Yet, it cannot be denied that the capacity of the service room is still limited. Thus it needs an improvement.

The same thing was also conveyed by Yolansawati Amir as Head of the Legal Metrology UPT of the Industry and Trade Office of Gorontalo Regency that the facilities and infrastructure were adequate because the institution received special allocation funds in 2019 from the State Budget of the Ministry of Trade of the Republic of Indonesia. However, they still need a laboratory to carry out inspections and as a place to store goods.

Implementation of Regulation Number 25 in 2009 Concerning the Public Services toward the Regional Organizations of 
Based on the research results through interviews, the facilities and infrastructure and other supports in the Gorontalo Regency OPPD are adequate. However, with limited reliable human resources and small service room capacity, thus making the provision of services to be small. So this is a severe concern for local governments to improve the quality of services in Gorontalo Regency.

\section{CONCLUSION}

Based on findings of the implementation of Regulation Number 25 in 2009 concerning the public services toward the Regional Organizations of Gorontalo District, namely where the implementation of public services by the regional organizations of Gorontalo District has been implemented based on the Procedure Operational Standard and the Legislation Provision, although it has not yet effective. As for the hindrances factors of the implementation of public services regulation at Regional Organizations of Gorontalo District are namely Human Resources and Facilities and Infrastructures than support the service provisions. Meanwhile, the roles and efforts to support the implementation of public services regulation at Regional Organizations of Gorontalo District are; a). Awareness of the officials and employees who work in public services; b). The regulation that becomes the foundation of service work; c). The organization as the instrument and system to enable the service activities mechanism to run; d). The employees' income has a function as the support of the activities implementation; e). The employees' skills; and f). The facilities in the implementation of a task in providing the services.

\section{ACKNOWLEDGMENTS}

With all humility, allow the researcher to thank the Chancellor of the University of Gorontalo, Ibrahim Ahmad who always supports and gives advice to all lecturers, including researchers, to continue producing beneficial scientific works for the development of science. Researchers would like to thank the Dean of the Faculty of Law, University of Gorontalo, Yusrianto Kadir who always supports Law Faculty Lecturers to continue producing innovative scientific works for the advancement of the quality and quality of Lecturers. Furthermore, the researchers also thank the Chairperson of the Institute for Research, Development and Community Service (LP3M) Universitas Gorontalo, Roy Marthen Moonti and his staff. The latter always facilitates the Lecturers at the University of Gorontalo in improving the quality and professionalism of lecturers. And all parties who have helped researchers both materially and non-materially.

Implementation of Regulation Number 25 in 2009 Concerning the Public Services toward the Regional Organizations of 


\section{REFERENCES}

Cahyadi, R. (2016). Inovasi Kualitas Pelayanan Publik Pemerintah Daerah. Fiat Justicia, 10(3), 569-586.

Hani, H. T. (2000). Manajemen Personalia dan Sumber Daya Manusia. BPFE.

Hasibuan, M. S. P., \& Hasibuan, H. M. S. P. (2016). Manajemen sumber daya manusia. Bumi Aksara.

Moenir, A. S. (2008). Manajemen Pelayanan Umum di Indonesia. Bumi Aksara.

Ndraha, T. (1999). Pengantar Teori Pengembangan Sumber Daya Manusia. Rineka Cipta.

Suparman, A. (2014). Penegakkan Hukum Terhadap Penyelenggaraan Pelayanan Publik. Jurnal Wawasan Hukum, 31(2).

Sutrisno, E. (2013). Manajemen Sumber Daya Manusia. Kencana.

Waluyo, B. (2002). Penelitian Hukum Dalam Praktek. Sinar Grafika.

Wibawa, K. C. S. (2019). Urgensi Keterbukaan Informasi dalam Pelayanan Publik sebagai Upaya Mewujudkan Tata Kelola Pemerintahan yang Baik. Administrative Law and Governance Journal, 2(2), 218-234. 